\title{
KONTRIBUSI WISATA BUDAYA "MEGIBUNG" TERHADAP PENGEMBANGAN PARIWISATA DESA ADAT ASAK
}

\author{
Ni Wayan Ari Sudiartini ${ }^{1}$ \\ Ni Ketut Murdani ${ }^{2}$ \\ I Dewa Nyoman Usadha ${ }^{3}$ \\ dan Agustina Nae Taek ${ }^{4}$ \\ Program Studi Manajemen, Fakultas Ekonomi, \\ Universitas Mahendradatta Bali \\ Jl. Ken Arok No. 12 Peguyangan Denpasar Utara, Bali 80115 \\ info@mahendradattauniversity.org
}

\begin{abstract}
ABSTRAK
Penelitian ini bertujuan untuk mengetahui tradisi megibung serta untuk mengetahui sejarah megibung. Tradisi Megibung diperkenalkan oleh Raja Karangasem yaitu I Gusti Agung Anglurah Ketut Karangasem sekitar tahun 1614 Caka atau 1692 Masehi. Tradisi ini dibawa oleh I Gusti Agung Anglurah Ketut Karangasem saat menang perang dalam menaklukan kerajaan-kerajaan di Sasak, Lombok. Dahulu, saat prajurit sedang makan, Sang Raja membuat aturan makan bersama dalam posisi melingkar yang dinamakan Megibung. Bahkan, Sang Raja ikut makan bersama dengan para prajuritnya Tata cara megibung yaitu warga menyiapkan makanan di atas nampan yang sudah dialasi daun pisang. Nasi utih yang diletakkan di wadah itu disebut gibungan, sedangkan lauk dan sayurnya disebut karangan atau selaan. Dari hasil penelitian yang sudah di lakukan yaitu bahwa tradisi megibung ini terdapat beberapa nilai yang terkandung yaitu terdiri dari ; (1). Nilai kekeluargaan.(2). Nilai kebersamaan,(3). Nilai relegius, dan (4). Nilai toleransi Kata Kunci : Desa Asak, Megibung, Wisata Budaya
\end{abstract}

\begin{abstract}
This study was aimed to determine the megibung tradition and to know the history of megibung. The Megibung tradition was introduced by Raja Karangasem namely I Gusti Agung Anglurah Ketut Karangasem around 1614 Caka or 1692 AD. This tradition was brought by I Gusti Agung Anglurah Ketut Karangasem when he won the war in conquering the kingdoms in Sasak, Lombok. In the past, when the soldiers were eating, the King made the rules of eating together in a circular position called the Megibung. In fact, the King joined in the meal with his soldiers. The megibung procedure is that the residents prepare food on a tray covered in banana leaves. Utih rice placed in the container is called a roll, while the side dishes and vegetables are called garlands or interrupts. From the results of research that has been done is that the megibung tradition there are several values
\end{abstract}

Ni Wayan Ari Sudiartini,

Ni Ketut Murdani, I Dewa Nyoman Usadha dan Agustina Nae Taek 
contained, consisting of; (1). Family values (2). Value of togetherness, (3). Religious value, and (4). Tolerance value

Keywords: Asak Village, Megibung, Cultural Tourism

\section{PENDAHULUAN}

Dalam peraturan daerah Bali telah dibuatkan peraturan khusus mengenai desa pakraman yang sekaligus memperkuat kedudukan dan landasan eksistensi desa pakraman.Peraturan daerah tersebut yaitu Peraturan Daerah Provinsi Bali Nomor 3 Tahun 2003 tentang Perubahan Kedua Peraturan Daerah Provinsi Bali Nomor 3 Tahun 2001 Tentang Desa Pakraman dan Lembaga Adat.Sebelumnya,istilah yang digunakan adalah desa adat sesuai Peraturan Daerah Nomor 6 Tahun 1986 tentang Kedudukan, Fungsi,dan Peranan Desa Adat sebagai Kesatuan Masyarakat Hukum Adat dalam Provinsi Daerah Tingkat I Bali.Desa adat sebagai desa dresta adalah kesatuan masyarakat 6arma adat di Provinsi Daerah Tingkat I Bali yang mempunyai satu kesatuan tradisi dan tata krama pergaulan hidup masyarakat umat Hindu secara turun temurun dalam ikatan Kahyangan Tiga(Kahyangan Desa)yang mempunya wilayah tertentu,harta kekayaan sendiri,dan berhak mengurus rumah tangganya sendiri.Namun,Peraturan Daerah 6 Tahun 1986 tentang Kedudukan,Fungsi,dan Peranan Desa Adat sebagai 31Kesatuan Masyarakat Hukum Adat dalam Provinsi DaerahTingkat I Bali kemudian dianggap tidak sesuai lagi dengan perkembangan zaman sehingga pada tahun 2001 diganti menjadi Peraturan Daerah Provinsi Bali
Nomor 3 Tahun 2001 dan mengalami perubahan menjadi Peraturan Daerah Bali Nomor 3 tahun 3003 tentang Desa Pakraman. Peraturan daerah ini pada dasarnya tetap berpegang pada falsafah Tri Hita Karana, sebagai landasan dalam pembuatan peraturan daerah di Bali.Dan selanjutnya, istilah desa yang digunakan di Bali adalah desa pakraman sesuai dengan maksud Peraturan Daerah Bali Nomor 3 tahun 2003. Dalam Perda ini diuraikan pengertian desa pakraman sebagai kesatuan masyarakat 6arma adat diProvinsi Bali yang mempunyai satu kesatuan tradisi dan tata krama pergaulan masyarakat umat Hindu secara turuntemurun dalam ikatan Kahyangan Tiga atau Kahyangan Desa yang mempunyai wilayah tertentu dan harta kekayaan sendiri serta berhak mengurus rumah tangganya sendiri. Dengan demikian keberadaan desa pakraman telah diakui secara formal menurut perundangundangan Negara Kesatuan Republik Indonesia dan menjadi landasan desa pakraman yang ada di Bali.

Berdasarkann uraian latar belakang di atas maka dapat di tarik beberapa rumusan masalah sebagai berikut :

1. Seperti apa proses upacara megibung di laksanakan?

2. Bagaimana pengaruh megibung terhadap pariwisata di Desa Adat Asak ?

3. Aspek apa saja yang terkandung dalam upacara megibung?

Ni Wayan Ari Sudiartini,

Ni Ketut Murdani,

I Dewa Nyoman Usadha

dan Agustina Nae Taek 


\section{KAJIAN TEORI}

\section{Pengertian Megibung}

Megibung merupakan kegiatan yang dimiliki oleh masyarakat Karangasem yang daerahnya terletak di ujung timur Pulau Dewata. Tanpa disadari Megibung menjadi suatu maskot atau ciri khas Kabupaten Karangasem yang ibu kotanya Amlapura ini. Tradisi Megibung sudah ada sejak jaman dahulu kala yang keberadaannya hingga saat ini masih kerap kali kita dapat jumpai. Bahkan sudah menjadi sebuah tradisi bagi Masyarakat Karangasem itu sendiri didalam melakukan suatu kegiatan baik dalam upacara Keagamaan, Adat maupun kegiatan sehari-hari masyarakat apabila sedang bercengkrama maupun berkumpul dengan sanak saudara. Saat ini kegiatan megibung kerap kali dapat dijumpai pada saat prosesi berlangsungnya Upacara Adat dan Keagamaan di suatu tempat di Karangasem. Seperti misalnya dalam Upacara Dewa Yadnya, Pitra Yadnya, Bhuta Yadnya, Rsi Yadnya dan Manusa Yadnya. Pada kegiatan ini biasanya yang punya acara memberikan undangan kepada kerabat serta sanak saudaranya guna menyaksikan prosesi kegiatan upacara keagamaan tersebut. Sehingga prosesi upacara dapat berlangsung seperti yang diharapkan.Proses penyembelihan babi pun dilakukan sebagai salah satu menu di dalam mempersiapkan hidangan yang disebut Gibungan ini. Daging babi diolah sedemikian rupa dan di kasi bumbu tertentu sehingga daging yang mentah menjadi menu pelengkap yang menggugah selera seperti sate, lawar, soup (komoh), Gegubah/lempyong, pepesan serta yang lainnya. Menu yang dihidangkan dalam Megibung tidaklah harus daging babi, namun dading ayam, kambing serta daging sapi pun tidaklah masalah.

\section{Pengertian Pariwisata}

Menurut KBBI, Pariwisata atau turisme adalah suatu perjalan untuk rekreasi atau liburan dan juga persiapan yang dilakukan untuk aktivitas ini. Pariwisata merupakan aktivitas melakukan perjalanan dengan tujuan memperoleh kenikmatan, mencari kepuasan, mengetahui sesuatu ,memperbaiki kesehatan, menunaikan tugas, berziarah dll. (James J. Spillane,1982) Pariwisata merupakan kegiatan perjalanan yang di lakukan oleh sementara waktu dari tempat tinnggal awal ke daerah tujuan dengan alasan bukan untuk menetap atau mencari nafkah melainkan hanya untuk memenuhi rasa ingin tahu, menghabiskan waktu senggang maupun libur dan bisa sajas menghabiskan uang yang terlalu banyak. (koen Meyers,2009)

\section{Pengertiann Wisata Budaya}

Wisata budaya adalah perjalanan yangdi lakukan oleh seseorang atau kelompok dengan mengunjungi tempat tertentu untuk tujuan rekreasi, pengembangan pribadi,atau mempelajari daya Tarik budaya dengan memanfaatkan potensi budaya dari tempat yang di kunjungi. Tujuan dari wisata budaya ini yaitu antara lain :untuk melestarikan alam,lingkungan,dan sumber daya. Untuk memajukan kebudayaan. Untuk

Ni Wayan Ari Sudiartini,

Ni Ketut Murdani,

I Dewa Nyoman Usadha

dan Agustina Nae Taek 
mengangkat citra bangsa. Untuk memupuk rasa cinta tanah air. Untuk memperkukuh jati diri dan kesatuan bangsa,dan untuk mempererat persahabatan antar bangsa.

\section{METODE PENELITIAN}

\section{Metode Pengumpulan Data}

Dalam penyusunan tulisan ini di pakai metode penelitian lapangan (Field Researsch) yaitu :penelitian yang mendapatkann data langsung dari masyarakat setempat. Dengan penelitian ini, penullis berusaha mendapatkan data yang ada kaitanya dengan permasalahan yang di bahas. Dalam rangka penelitian lapangan, penulis menggunakan Teknik pengumpulan data interview atau wawancara yaitu proses tanya jawab secara lisan, dan Teknik pengumpula data observasi atau pengamatan secara langsung dengan obyek yang diteliti.

\section{Metode Analisis Data}

Dalam tahap ini penulis menggunakan teknik analisi data statistika yaitu teknik bagaimana cara-cara mengumpulkan data atau fakta,mengolah,menyajikan, dan menganalisa,penarikan kesimpulan serta pembuatan keputusan yang cukup beralasan berdasarkan fakta dan penganalisaan yang di lakukan

\section{HASIL DAN PEMBAHASAN \\ Hasil}

Berdasarkan hasil wawancara dengan Ketut Sumetra selaku warga di Desa Adat Asak diperoleh informasi secara lisan maupun tertulis sebagai berikut: Menurut Bendesa Desa Adat Asak, tradisi megibung sudah dilakukan sejak jaman dahulu oleh para leluhur dimana dalam tradisi tersebut ternyata banyak mengandung nilai-nilai kesopanan, etika, perilaku yang secara implisit ada didalamnya.Megibung merupakan tradisi makan bersama dalam satu wadah dengan posisi duduk melingkar yang biasanya berjumlah 6-8 orang yang dilaksanakan secara turun temurun oleh masyarakat Karangasem.Mengenai asal muasal megibung yang dilaksanakan di Bali khususnya di Karangasem (sebagian di Lombok khususnya Lombok Barat) ada beberapa macam pendapat: "Megibung dilaksanakan pada pemerintahan Kerajaan Karangasem yang pada waktu itu berhasil menaklukkan kerajaan-kerajaan di Sasak, (Lombok sekarang). Kemudian beliau memberikan penghargaan dan selalu menekankan rasa kebersamaan untuk mencapai tujuan dan salah satunya perintah beliau adalah melalui makan bersama yang sampai saat ini disebut megibung" Mustika, 2017) Kalau disimak atau diperhatikan pelaksanaan tradisi megibung sebenarnya mengandung pendidikan moral dan etika yang sangat dalam, ini tercermin dari mulai mempersiapkan, menata, menghidangan, dan menyantap/makan sampai selesainya acara.Megibung dimaksud dilakukan secara tertib dan teratur sebagaimana dalam prakteknya yang sering kita lihat pada acara-acara pancayadnya. Tradisi Megibung mengandung philosofi yang sangat tinggi yang diajarkan oleh leluhur terdahulu kepada kita khususnya generasi mendatang yaitu: (1).Selalu mengutamakan/mempersembahkan

Ni Wayan Ari Sudiartini,

Ni Ketut Murdani,

I Dewa Nyoman Usadha

dan Agustina Nae Taek 
terlebih dahulu kehadapan Ida Sang Hyang Widhi Wasa, sebagai sujud bakti dan astiti; (2).,Pendidikan moral (etika, tata tertib, sopan santun,kesabaran, rasa kebersamaan, kekeluargaan dan saling menghargai); (3).Proses sosialisasi sesama manusia, yang awalnya tidak saling mengenal,maka pada saat megibung kita mendapat sahabat, dan persaudaraan menjadi luas.; (4).Melalui megibung tidak terjadi kastalisasi artinya kedudukan kita sama tidak memandang dari kasta mana yang ikut megibung(Mustika, 2017) Dengan demikian tradisi megibung sarat mengandung pendidikan moral yang sejak awal kita diajarkan untuk beretika , dimana hanya persoalan makan saja sudah seharusnya mengikuti sopan santun, apalagi perilaku lainnya yang terutama bisa menghargai dan menghormati yang lebih tua.

\section{Pembahasan}

Megibung merupakan salah satu tradisi warisan leluhur,dimana merupakantradisi makan bersama dalam satu wadah. Selain makan bisa sampai puas tanpa rasa sungkan, megibung penuh nilai kebersamaan, bisa sambil bertukar pikiran,saling mengenal, lebih mempererat persahabatan

sesame warga. Makan bersama atau megibung ini, dalam setiap satu wadah terdiri dari 6-8orang, memang merupakan wujud kebersamaan tidak ada perbedaan antara orang kaya maupun miskin juga perbedaan kasta ataupun warna, semua duduk berbaur dan makan bersama, tapi pada perkembangan berikutnya antara laki dan perempuan dipisahkan, tapi kalau masih dalam satu keluarga ataupun tetangga, mereka memilih bergabung. Tradisi megibung sering digelar berkaitan dengan berbagai jenis upacara adat dan agama (Hindu), seperti upacara potong gigi,otonan anak, pernikahan, ngaben, pemelaspasan, dan piodalan di Pura. Seiring dengan kemajuan teknologi di berbagai bidang saat ini, tradisi megibung mengalami pergeseran dimana masyarakat mencari aspek kepraktisan dengan mengadopsi tata cara makan secara nasional yaitu prasmanan. Strategi dalam penelitian ini adalah suatu kesatuan rencana yang komprehensif dan terpadu untuk mencapai keunggulan bersaing dalam mencapai tujuan yang diwujudkan dalam bentuk program-program pengembangan. Siagian ,(2004) Dalam hal ini pengembangan tradisi megibung untuk mampu dilestarikan sebagai bagian dari pelestarian budaya yang adiluhung ( Hurlock, E. B., 1997)(Setiawan, 2007).

Proses Upacara Megibung Persiapan (Tahap Mempersiapkan)

Pekerjaan awal yang perlu dilakukan sebelum tradisi megibung adalah menentukan jenis Yadnya yang dilakukan dan banten beserta runtutannya yang perlu disiapkan karena akan terkait dengan ulam banten (baca Be Karangan) sebagai kelengkapan Banten, stelah diketahui baru menentukan Kerabat/kerama yang akan terlibat dalam menyiapkan sesaji itu sehingga mendapat perhitungan pasti berapa keperluan daging dan kelengkapan lainnya (termasuk menyiapkan nasi), cara pengerjaannyapun dilakukan secara bersama-sama dan penuh rasa

Ni Wayan Ari Sudiartini,

Ni Ketut Murdani,

I Dewa Nyoman Usadha

dan Agustina Nae Taek 
kekeluargaan dan kegotongroyongan yang tercermin mulai saat menyiapkan peralatan sampai membagi pekerjaan atau tugas

\section{Tata Cara Makan /Megibung}

Posisi megibung adalah melingkar yang menurut tradisi terdiri dari 8 (delapan) orang sesuai arah mata angin dan ditengah adalah hidangan (gibungan). Kalau diperhatikan secara philosofi dapat diartikan bahwa pengaturan tempat duduk sudah mengandung nilai tinggi yaitu 8 terkait dengan astadala ditambah di tengah menjadi Sembilan (9) yang artinya kita selalu ingat akan Sembilan kekuatan yang disebut Dewata Nawa Sanga yang menciptakan keseimbangan dan keharmonisan alam semesta ini artinya sebelum kita memulai menyantap makanan/hidangan gibungan itu, selalu didahului dengan memohon kehadapan Beliau yang telah menciptakan alam dengan segala isinya, memberikan kebahagiaan, keselamatan dan kesejahteraan bagi mahluk yang ada di buana (dunia) ini. Artinya setiap pelaksanaan tradisi megibung harus didahului dengan memohon keselamatan alam beserta isinya kehadapan Ida Sang Hyang Widhi Wasa. Namun seiring perkembangannya sekarang jumlah anggota dalam satu sela terdiri dari 6 orang , dengaan alasan factor kenyamanan duduk berenam, walaupun secara etika tidak mengurangi arti atau makna megibung itu sendiri. Dari penataan tempat duduk yangmelingkar itu yang terdiri dari 8 (delapan) orang ada keunikan dan etika di dalamnya yaitu:

(1). Diantara 8 (delapan) orang yang duduk melingkar itu kemungkinan belum saling kenal;

(2).Tradisi yang masih kental di masyarakat masih berlaku golongangolongan /strata sosial tertentu, dimana tempat duduk di saat megibung kondisi strata tidak berlaku;

(3). Bagi golongan tertentu yang dianggap tinggi atau krama yang dianggap lebih tua selalu dipersilahkan duduk terlebih dahulu dan posisinya di arah utara atau timur tepatnya timur laut sebagai penghormatan.;

(4). Krama yang lainnya dipersilahkan duduk selanjutnya menempati posisi yang sudah tersedia;

(5). Anggota yang duduk di posisi timur laut berperan sebagai pengenter artinya yang bertugas mengisi lauk pauk perjenis lauk ke atas nasi gibungan sesuai urutan/tahapannya, dilanjutkan dengan mengucapkan sampun sayaga (sudah siap untuk menikmati);

(6). Menikmati hidangan didahulukan orang yang lebih tua, dilanjutkan oleh anggota yang lain. Pada saat mulai megibung ada aturan-aturan yang harus diikuti antara lain; nurunkan/membagikan daging karangan didahului dengan sayur, adonan lawar, daging/balung, terakhir sate.; Pada saat makan tidak boleh menaruh sisa makanan tersebut di atas tempat gibungan,melainkan harus ditaruh dibawah/ di muka tempat duduk kita.;makanan tidak boleh berserakan, apalagi lewat ke tempat duduk di sebelahnya;Nasi atau daging hanya boleh

Ni Wayan Ari Sudiartini,

Ni Ketut Murdani,

I Dewa Nyoman Usadha

dan Agustina Nae Taek 
diambil yang ada dihadapan kita dan tidak boleh mengambil makanan di tempat atau wewidangan orang lain di sebelah kita.;Membagi daging/lauk tidak boleh menggunakan mulut; Air minum yang disediakan pada kendi (Caratan), pada saat minum, bibir tidak boleh menyentuh mulut kendi;Setelah selesai megibung tidak boleh mendahului bangun atau pergi, melainkan harus terlebih dahulu menunggu semua kelompok yang megibung sudah selesai makan,artinya mulai bersama-sama, selesaipun bersama-sama.

\section{Pengaruh Megibung Terhadap}

\section{Pariwisata}

Sampai saat ini tradisi megibung masih tetap berlangsung dan tetap dipertahankan dari generasi ke generasi. Walaupun dalam perjalanannya tradisi megibung ini mengalami perubahanperubahan, dikarenakan adanya pengaruh globalisasi. Perubahanperubahan seperti halnya peralatan yang digunakan pada masa lalu dan masa kini mengalami perubahan yang sangat pesat. Meskipun di beberapa desa di luar Desa Adat Asak tradisi megibung sudah mulai terkikis karena adanya pola makan yang lebih modern seperti makan prasmanan yang sedang trend di masyarakat saat ini. Makan dengan prasmanan dianggap lebih modern dan lebih tinggi status sosialnya. Masyarakat yang mengadakan acara yadnya, yang menghidangkan makan pada para tamunya dianggap kuno dan ketinggalan jaman, serta memiliki status sosial yang rendah. Sebaliknya masyarakat yang mengadakan acara yadnya yang menyuguhkan makan dengan cara

prasmanan dianggap sebagai keluarga pejabat yang modern serta memiliki status sosial yang tinggi. Anggapananggapan seperti itu tentu saja akan mengancam eksistensi tradisi megibung. Karena, akan dapat menyebabkan tradisi ini ditinggalkan masyarakat. Akan tetapi hal tersebut tidak terjadi dalam masyarakat Desa Adat Asak, hal tersebut terbukti sampai saat ini tradisi megibung masih tetap dilaksanakan oleh masyarakat Desa Adat Asak. Setiap dalam upacra keagamaan seperti upacara dewa yadnya, pitra yadnya, maupun manusia. Berdasarkan hasil pengamatan penulis, diketahui bahwa dalam megibung melalui beberapa proses yaitu proses persiapan, proses pengolahan, dan proses megibung. Adapun upaya pemerintah desa mempertahankan tradisi megibung dari segi sebagai penentu kebijakan kepada kelihan banjar dinas agar menyampaikan kepada masyarakat bahwa megibung adalah tradisi yang harus dijaga dan dilestarikan untuk mempererat persatuan dan kesatuan lingkungan. Usaha-usaha yang sudah dilakukan oleh pemerintah dan masyarakat Desa Adat Asak untuk melestarikan tradisi megibung diantaranya dengan terus mengadakan megibung disetiap kegiatan di masyarakat, sehingga secara tidak langsung megibung sudah menjadi kebiasaan di masyarakat.Adapun upayaupaya pemerintah desa dalam mempertahankan tradisi megibung kepada masyarakat untuk menghimbau agar tetap melaksanakan tradisi

Ni Wayan Ari Sudiartini,

Ni Ketut Murdani,

I Dewa Nyoman Usadha

dan Agustina Nae Taek 
megibung. Tidak ada kendala dan tidak ada ancaman dalam pelestarian tradisi megibung.

\section{Aspek Yang Terkandung Dalam Upacara Mengibung \\ 1. Nilai kekeluargaan}

Pelaksanaan megibung telah memupuk nilai kekeluargaan di dalam kehidupan masyarakat Desa Adat Asak.Hal tersebut terlihat dari proses megibung yang pengerjaannya selalu dilakukan secara musyawarah. Semua proses pembuatan gibungan mulai dari persiapan sampai selesai megibung dilakukan untuk masyarakat Desa Adat Asak. Dalam megibung orang tidak memandang status sosial, tidak membedakan kaya atau miskin, ganteng atau cantik, berkasta atau tidak. Semua orang duduk menjadi satu dan makan makanan yang sama dalam satu wadah. Dengan cara seperti itu akan menghindarkan seseorang dari rasa ego yang dapat menjadi jurang pemisah di masyarakat karena adanya perbedaan status sosial dan mempererat rasa kesatuan di dalam masyarakat.

\section{Nilai kebersamaan}

Semangat gotong royong sangat kental terlihat dalam pelaksanaan megibung, nilai kebersamaan tersebut terpancar sejak mulai dari persiapan bahan dan alat sampai pada proses selesaI megibung. Ketika pelaksanaan upacara yadnya masyarakat Desa Adat Asak. bahu membahu serta bekerjasama guna menyiapkan bahan dan alat yang akan digunakan untuk membuat gibungan. Semangat kerja keras dari masyarakat Desa Adat Asak.tersebut dilaksanakan secara tulus dan tanpa mengharapkan imbalan. Setelah semua persiapan selesai, maka gibungan akan disebar mencari tempat yang luas dan tuan rumah akan mempersilahkan undangan untuk megibung, kemudian para undangan akan saling mengingatkan untuk makan dan masing-masing undangan akan membagi diri membentuk kelompok menjadi delapan orang dan ecara bergilir untuk melaksanakan megibung. Sementara undangan yang belum dapat giliran makan secara sukarela akan melayani semua permintaan yang diperlukanoleh undangan yang sudah dapat giliran makan seperti air minum, sayur, dan yang lainnya. Begitu juga sebaliknya, undangan yang sudah selesai makan akan melayani undangan yang belum mendapat giliran makan.

\section{Nilai religius}

Nilai lain yang juga terkandung di dalam tradisi megibung adalah nilai-nilai religius. Nilai-nilai religius ini sangat kental terlihat dalam setiap tahapan maupun proses pelaksanaan megibung. Hal tersebut dikarenakan, secara tidak langsung tradisi megibung sangat berkaitan dengan upacara yadnya baik upacara manusia yadnya, pitra yadnya, maupun dewa yadnya. Dikatakan demikian karena kegiatan megibung biasanya dilaksanakan saat ada upacara yadnya. Megibung

tidak hanya sekedar makan bersama, dalam megibung terdapat banyak makna yang terkandung dalam tradisi tersebut,oleh karena itu dalam setiap tahapan pembuatan gibungan selalu berpedoman pada ajaran agama hindu. Nilai-nilai religious tersebut terkandung dalam proses megibung, yaitu ngejot.

Ni Wayan Ari Sudiartini,

Ni Ketut Murdani,

I Dewa Nyoman Usadha

dan Agustina Nae Taek 
Ngejot adalah proses sebelum pelaksanaan megibung yakni dengan menghaturkan gibungan kepada para leluhur, para dewa, dan bhuta kala, sebagai wujud syukur kepada tuhan yang maha esa, ida sanghyang widhi wasa, karena telah diberikan rejeki yang melimpah. Sebelum megibuung dilaksanakan, tuan rumah yang memiliki acara akan terlebih dahulu ngejot kepada para dewa dan leluhur serta bhuta kala agar mendapatkan pahala atau surga syuta.

\section{Nilai Toleransi}

Toleransi dalam tradisi megibung ialah saling menghargai antar sesama dan tidak membeda-bedakan status sosial yang ada dalam masyarakat tersebut dan saling menjaga perasaan atau saling menghormati. Dengan adanya nilai toleransi maka tradisi megibung dapat dilaksanakan dengan baik.

\section{Kesimpulan}

Tradisi megibung adalah salah satu tradisi yang memiliki nilai -nilai etika, moral, dan kesopanan yang tinggi yang sangat mulia yang di dalamnya banyak terkandung makna yang dapat meningkatkan rasa kekeluargaan dan semangat kebersamaan tanpa membedakan derajat, status sosial.; Proses persiapan, pengolahan, dan penyajian hidangan megibung secara umum dilakukan bersama-sama oleh anggota banjar (krama) utamanya krama laki-laki, dan dipimpin oleh seorang juru patus atau belawa, hal bermakna semangat gotong royong yang sangat tinggi.Selanjutnya adanya opini masyarakat yang menganggap tradisi megibung kurang elegan atau kurang mewah dari sisi status sosial, kurang praktis, pemborosan, berakibat beralihnya pola makan bersama ke pola prasmanan, padahal sesungguhnya pola megibung jauh memiliki makna yang mendalam yang diajarkan secara tidak langsung oleh para leluhur terdahulu. Oleh karena itu sudah seharusnya menjadi kewajiban generasi muda untuk melestraikan, menjaga tradisi-tradisi yang luhur, syarat makna. Khusus di desa Adat Asak, tradisi megibung akan dimasukkan dalam prarem (awig-awig desa) sebagai salah satu peraturan yang wajib dilaksanakan minimal pada acaraacara adat. Selain itu seiring kemajuan IPTEKS di era globalisasi saat ini, peranan media sosial, internet menjadi sangat penting. Oleh karena itu strategi lainnya yaitu melalui pengenalan tradisi megibung pada situs website, sehingga tradisi megibung bisa dikenal luas oleh masyarakat Bali secara khusus dan masyarakat lainnya secara umum. Dengan demikian tradisi ini akan tetap lestari sepanjang masa.

\section{Saran}

Seiring berjalannya waktu maka akan semakin banyak terjadi suatu perubahan, hal ini akan menjadi sebuah tantangan saran saya bagi masyarakat desa Adat Asak untuk tetap menjaga tradisi megibung.sehingga Tradisi megibung tidak menjadi tradisi yang punah

\section{Daftar Pustaka}

Ida,Wikipedia.org .megibung

Ni Wayan Ari Sudiartini,

Ni Ketut Murdani,

I Dewa Nyoman Usadha

dan Agustina Nae Taek 
karangasemkab.go.id/index.php/baca artikel/61/Ritual-Unik-di-DesaAdat-Asak-

Karangasem-min-Nyepeg-Sampi-

Beramaiminramai-untuk-

Menetralisir-Alam

docplayer.info/39526160 tinjauan-

umum-tentang-desa-pakraman-

asak-karangasem-

2-1-gambaran-umum-desa-pakramanasak-karangasem.html

Bali-travelnews.com.2017. Tradisi-unikdi-desa-asak-seluruh-rangkaian-

truna-adat/ ritualdigarap-

Meyers, Koen. 2009. Pengertian Pariwisata, Jakarta: Unesco Office.

Mustika. (2017). Pengaruh Corporate Social Responsibility, Ukuran Perusahaan, Profitabilitas, Leverage, Capital Intensity, dan Kepemilikan Keluarga Terhadap Agresivitas Pajak. JOM Fekon, Vol.4, No.1

Spilane, James. 1985. Ekonomi Pariwisata. Yogyakarta : Kansius

Siagian,Sondang P, 2004, Teori Motivasi Dan Aplikasinya,Bina Aksara Jakarta

Ni Wayan Ari Sudiartini,

Ni Ketut Murdani,

I Dewa Nyoman Usadha

dan Agustina Nae Taek 